\title{
Miliary tuberculosis with haemophagocytic syndrome and pneumothorax
}

\author{
*Abhilash K Thomas ${ }^{1}$, Mili Thomas ${ }^{1}$, Prameela Joji ${ }^{1}$, Asokkumar Gopalannair ${ }^{1}$ \\ Sri Lanka Journal of Child Health, 2018; 47(1): 71-73 \\ DOI: http://dx.doi.org/10.4038/sljch.v47i1.8434 \\ (Key words: Haemophagocytic syndrome, tuberculosis, choroid tubercles, pneumothorax)
}

\section{Introduction}

Haemophagocytic syndrome (HPS) is a nonmalignant proliferative disorder affecting the antigenprocessing macrophages resulting in uncontrolled haemophagocytosis and upregulation of inflammatory cytokines ${ }^{1}$. We report a case of miliary TB with HPS in a 2 month old infant.

\section{Case report}

A 2 month old baby girl, born to a primigravida mother, presented with fever of one month duration. There was third degree parental consanguinity. She was born at term by caesarean section with a birth weight of $3.5 \mathrm{~kg}$. There were no antenatal or neonatal issues. Social smile was attained. BCG had been administered at birth and routine vaccination at six weeks was taken. On examination, she was afebrile, liver was palpable $4 \mathrm{~cm}$ below costal margin and the spleen palpable $2 \mathrm{~cm}$ below costal margin. There was no lymphadenopathy and other systems were normal.

Haemoglobin level was $7.4 \mathrm{~g} / \mathrm{dl}$, the white blood cell count $9.9 \times 10^{9} / \mathrm{L}$ (polymorphs 52\%, lymphocytes $42 \%$, monocytes $4 \%$ ) and the platelet count $149 \times$ $10^{\%} / \mathrm{L}$. The C-reactive protein was $83.9 \mathrm{mg} / \mathrm{L}$ and the erythrocyte sedimentation rate $13 \mathrm{~mm}$ in first hour. The peripheral blood film showed neutrophilia with toxic granules and a shift to the left. Liver and renal function tests were unremarkable. Chest x-ray showed multiple disseminated nodules bilaterally suggestive of miliary TB (Figure 1), Ultrasonogram showed an enlarged liver with homogeneous parenchymal echoes and an enlarged spleen with multiple hypoechoic lesions.

\footnotetext{
${ }^{1}$ Kerala Institute of Medical Sciences, India

*Correspondence: abhilashkthomas80@gmail.com (Received on 20 September 2016: Accepted after revision on 21 October 2016)

The authors declare that there are no conflicts of interest

Personal funding was used for the project.

Open Access Article published under the Creative

Commons Attribution CC-BY CC (i)
}

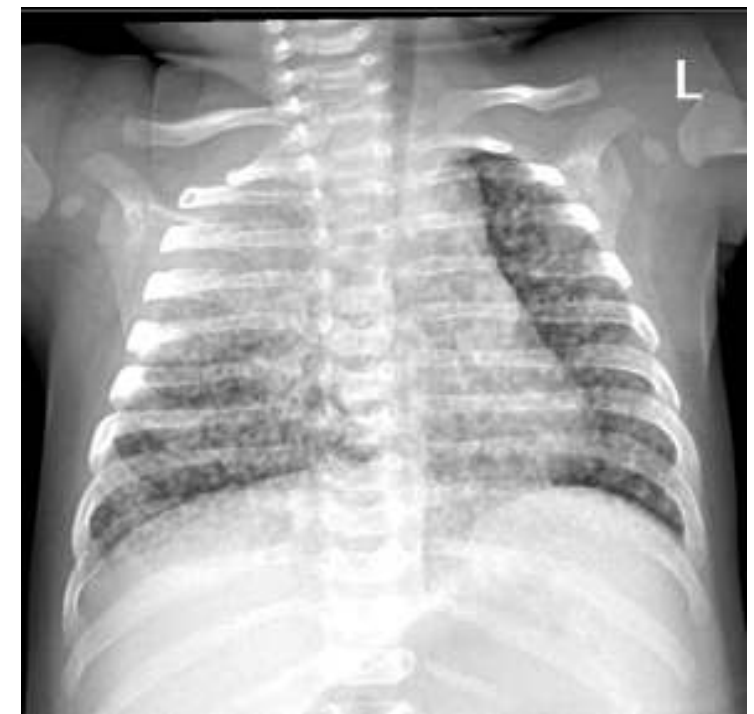

Figure 1: Chest x-ray showing miliary nodules bilaterally

Cerebrospinal fluid (CSF) examination was normal and blood culture was sterile. Bone marrow aspiration cytology showed a cellular marrow with mild erythroid hyperplasia and adequate megakaryocytes. Haemophagocytosis (of erythroid, myeloid cells and platelets) was seen. There were no abnormal infiltrates (Figure 2).

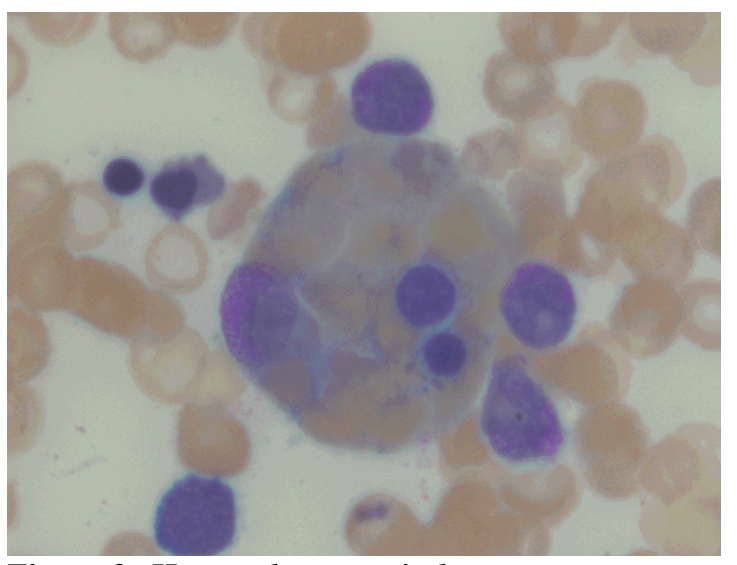

Figure 2: Haemophagocyte in bone marrow smear 
Gastric aspirate for acid fast bacilli (AFB) was twice negative. Computed tomography guided aspirate taken from the lungs showed numerous AFB (Figure 3). Fundus examination showed choroid tubercles.

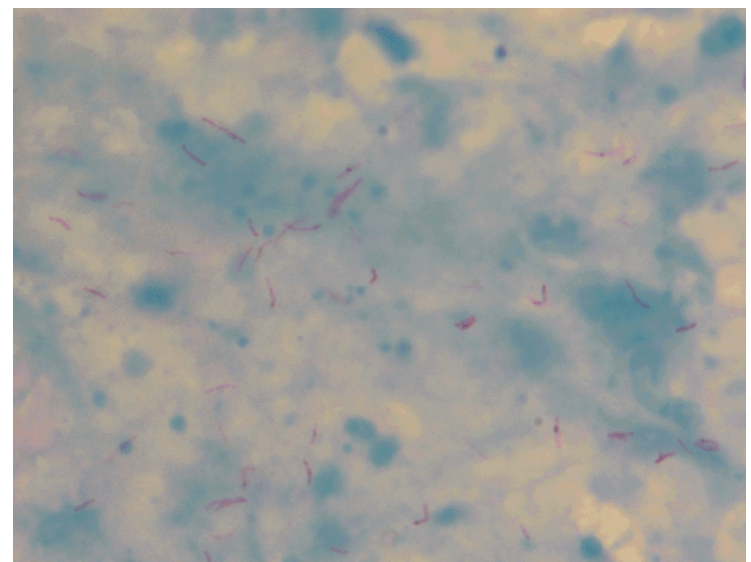

Figure 3: Acid fast bacilli in lung aspirate

In view of the haemophagocytic bone marrow, further investigations were done to rule out HPS. The fibrinogen level was $1.17 \mathrm{~g} / \mathrm{L}$ (normal $<1.50 \mathrm{~g} / \mathrm{L}$ ) and the serum triglyceride level was $1.76 \mathrm{mmol} / \mathrm{L}$ (normal $\geq 2.99 \mathrm{mmol} / \mathrm{L}$ ), Serum ferritin was 1169 $\mathrm{mcg} / \mathrm{L}$ (normal $\geq 500 \mathrm{mcg} / \mathrm{L}$ ). A diagnosis of miliary TB with secondary HPS was made. Human immunodeficiency virus (HIV) was negative. Serum IgM, IgG and IgA levels were normal.

There was no history of TB in family members and chest $\mathrm{x}$-rays of parents were normal. In both parents sputum was negative for AFB. Both parents were screened for HIV and it was negative. Anti-TB treatment was started with isoniazid $10 \mathrm{mg} / \mathrm{kg} / \mathrm{day}$, rifampicin $\quad 15 \mathrm{mg} / \mathrm{kg} /$ day, pyrazinamide $30 \mathrm{mg} / \mathrm{kg} /$ day and streptomycin $20 \mathrm{mg} / \mathrm{kg} /$ day. Child responded well to the treatment and fever subsided.

After 4 weeks of treatment, infant was re-admitted with a history of rapid breathing. On examination, infant had tachypnoea, chest retractions and air entry diminished in left side with apex beat shifted towards right side. Chest x-ray showed left sided pneumothorax (Figures 4 and 5) which was managed with intercostal drainage tube. Xpert MTB/RIF showed mycobacterium tuberculosis sensitive to rifampicin.

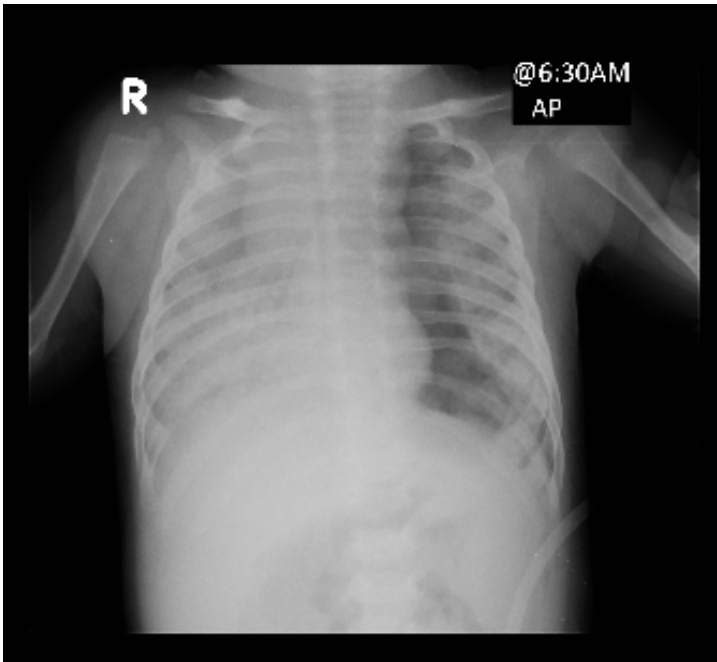

Figure 4: Chest $x$-ray showing left pneumothorax

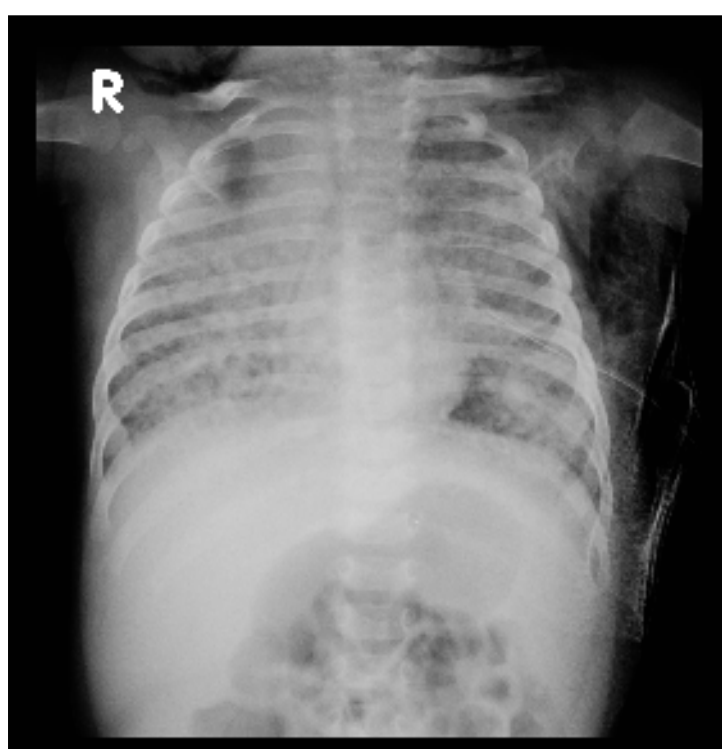

Figure 5: Chest $x$-ray showing resolution of pneumothorax

The baby was transferred in a stable condition to a tertiary medical care centre near the home town of the parents on their request. Later it was learnt that after a week baby developed pulmonary haemorrhage and expired.

\section{Discussion}

HPS is also known as haemophagocytic lymphohistiocytosis (HLH). A macrophage activation syndrome with haemophagocytosis may develop as a result of a strong immunological activation of mononuclear phagocyte system secondary to a severe infection ${ }^{2}$. HPS has been associated with Epstein- 
Barr virus, cytomegalovirus and herpes simplex virus $^{3}$. According to the Histiocytic Society Guidelines $2004^{2}$, diagnosis of HLH can be established if 5 out of 8 diagnostic criteria are fulfilled (i) Fever more than 7 days, (ii) Splenomegaly, (iii) Cytopenia (>2 lineage) haemoglobin level less than $9 \mathrm{~g} \%$, platelet count less than $100,000 / \mathrm{cu} \mathrm{mm}$ and absolute neutrophil count less than 1,000/cu mm. (iv) Hypertriglyceridaemia (>265 mg/dl), (v) Haemophagocytosis (bone marrow, spleen, lymph node), (vi) Low or absent Natural Killer Cell activity, (vii) Hyperferritinaemia (500 $\mathrm{mcg} / \mathrm{dl}$ ), (viii) Increased soluble CD25 > $2400 \mathrm{u} / \mathrm{ml}$. In our case, the diagnosis of HLH was established as 5 out of 8 criteria were fulfilled.

In our case, gastric aspirates for AFB were negative but lung aspirate confirmed the diagnosis of TB by showing numerous AFB. Schaaf HS et al had observed that the commonest source of confirmatory cultures of Mycobacterium tuberculosis in infants was gastric aspirate, but all available body fluids and biopsies have to be used to confirm the diagnosis ${ }^{4}$. Choroid tubercles which were present in this child, are more common in children and are said to be pathognomonic of miliary $\mathrm{TB}^{5}$. In our case, the mother did not have overt TB. This is in accordance with a report that up to $75 \%$ mothers whose newborn had TB were asymptomatic before delivery ${ }^{6}$.

Miliary TB in infants and children is not commonly associated with pneumothorax. Only a few cases of miliary TB complicated with pneumothorax have been reported ${ }^{7}$. The exact pathogenesis of pneumothorax is not clear in miliary TB. One mechanism might be the formation of small areas of confluent sub-pleural miliary nodules that undergo caseation necrosis with subsequent rupture of the caseation into free pleural space. Alternatively, a bullous lesion might form near the miliary tubercles which rupture to produce a pneumothorax ${ }^{8}$.

\section{References}

1. Palazzi DL, McClain KL, Kaplan SL. Haemophagocytic syndrome in children: An important diagnostic consideration in fever of unknown origin. Clinical Infectious Diseases 2003; 36: 306-12.

https://doi.org/10.1086/345903

PMid: 12539072

2. Henter JI, Home A, Arico M, Egeler RM, Filipovin AH, Imashuku S, et al. HLH-2004: Diagnostic and therapeutic guidelines for haemophagocytic lymphohistiocytosis. Pediatric Blood Cancer 2007; 48:124-31. https://doi.org/10.1002/pbc.21039 PMid: 16937360

3. Ladisch S. Histiocytosis Syndromes of Childhood. In: Kleigman, Stanton, St.Geme, Schor, and Behrman editors. Nelson Textbook of Pediatrics $20^{\text {th }}$ ed. Philadelphia: Saunders Elsevier. 2016. p. 2487-9. PMCid: PMC4936598

4. Schaaf HS, Gie RP, Beyers $N$, et al, Tuberculosis in infants less than 3 months of age. Archives of Disease in Childhood 1993; 69:371-4.

https://doi.org/10.1136/adc.69.3.371

PMid: 8215548 PMCid: PMC1029523

5. Sharma SK, Mohan A, Sharma A. Challenges in the diagnosis \& treatment of miliary tuberculosis. Indian Journal of Medical Research 2012; 135(5):703-30. PMid: 22771605 PMCid: PMC3401706

6. Adhikari M, Pillay $\mathrm{T}$, Pillay DG. Tuberculosis in the newborn: an emerging disease. Pediatric Infectious Disease Journal 1997; 16:1108-12. https://doi.org/10.1097/00006454199712000 $-00003$

PMid: 9427454

7. Taşar MA, Bostanci I, Aslan S, Yilmaz $\mathrm{R}$, Dallar Y. Recurrent pneumothorax at an infant with miliary tuberculosis. Tuberk Toraks. 2005; 53(4):394-6.

PMid: 16456740

8. Liu WL, Wang HC, Luh KT, Yang PC. Recurrent bilateral pneumothoraces: a rare complication of miliary tuberculosis. Journal of the Formosan Medical Association 2008; 107:902-6. https://doi.org/10.1016/S09296646(08)6020 8-9 